\title{
Research on the School Spirit and the Schooling Strategy of Local New - built Universities
}

\section{-from the School Color and the Mascot of American Universities}

\author{
Jichun Wang \\ Mianyang Teachers’ College, Mianyang, Sichuan, China, 621000
}

Keywords: Local New Undergraduate Colleges, School Color, Mascot, School Spirit, Culture School

\begin{abstract}
School spirit is the soul of the school and the pursuit of value, is the development of colleges and universities rely on and carrier. On the basis of elaborating the origin, manifestation and value of American university color and mascot, this paper puts forward the concrete strategy of cultural school establishment on the basis of the problems in the development of local new undergraduate colleges, so as to provide new ideas, new perspective for local colleges and universities.
\end{abstract}

\section{The Development and the Form of Expression of American University Color}

The United States from the primary school stage, each school has its own school color. In all kinds of competitions, especially in sports competitions, school color will become the school's spiritual symbols. This tradition continues from elementary school to early, high school, and eventually gets sublimated in college.

American university school color is usually divided into red, blue, yellow, brown, purple, green and colored "flower" family [1]. "Flower" is generally orange, purple, red and green-based colors, and then with a representative of a metal color composition, there are some schools with the flag of red, white, blue three colors as school color. To Harvard, for example, crimson is synonymous with Harvard, Harvard campus building to deep red-based, sports team named Harvard Crimson, the school newspaper to "Harvard Crimson" named. Harvard even with the red, green and blue color law provides that the deep red belongs to Harvard [2]. Obviously, crimson has become a symbol of Harvard spirit.

Although the United States is to highlight the personality, individualistic culture-oriented countries, but the meaning of school color is the students of the collective recognition and understanding, is a unique campus cultural products.

\section{The Popularity and Its Significance of American Mascots}

College mascot originated in the late 19th century, in the 100 years of development history and there have been a variety of different forms of mascot [3]. Almost all colleges and universities in the United States have mascots, mascots are usually with the school badge, school motto, school song, etc. as a unique symbol of the school, active in the school of various large-scale activities (such as school games, graduation ceremony or new activities), auspicious things have become the school's most vivid, and the most dynamic and characteristic of the form of expression.

American mascots of the university, as a whole can be divided into animal class, plant class, character class, cartoon image and virtual form class. Among them, the largest proportion of animal species, nearly a hundred colleges and universities to eagles, tigers as mascot. Harvard University with the priest John Harvard as the mascot, Stanford University to the tree, Delta State University to 
okra as a mascot; there are some schools to cartoon image or logo symbols, such as St. Louis University invincible lucky star (Billikens), Egypt Murray University's white skull (Dooley) and so on [4]. Although the American mascot in the form of different forms, but the school's influence and the connotation of the given is very similar. It is the university's unique identity and cultural interpretation, is a symbol of the spirit of the university, it is the physical style of the school.

The school mascot and school color worship in the United States college sports league is particularly spectacular (especially football and basketball game), the organizers arranged to school color-based color, a large number of publicity highlights the school color, lovely Mascot "walk" among the crowd, the students dressed in their school color of the clothing appeared in the venue, and the local residents will be dressed in such clothing to watch the game, a university culture seems to have become Local community culture, not only students fanatical, residents are also infected. At this point, a color, a symbol has represented a spirit, a culture.

\section{The School Spirit and Culture Strategy of the Local New Undergraduate Colleges}

Local new undergraduate colleges not only need to improve the teaching hardware and software facilities, improve the personnel training strategy, improve the quality of teachers work hard, but also try to culture school, to create a clear spirit of the school, unity and teachers and students, and seek common development. Specifically, start with the following:

Beautify the Campus Material Landscape and Show the School Spirit. Campus material culture is the material basis of the spiritual culture of the university, is a special material "cultural field", can play a "Run things fine silent" role [5]. Any well-known university always has some special landscape, these landscapes are the accumulation of school culture, is the embodiment of the campus customs. When students enter the campus, the campus landscape will be integrated into the student's life, as part of the student's spiritual world. All the material landscape of the university has gone beyond the landscape itself, a symbol of the spirit of the school, the martyrs Pavilion of Lanzhou University - the birthplace of crazy English, students see the struggle of the figure; Hainan University Dongpo Lake, highlighting Mr. Dongpo with the flow, optimistic and open-minded temperament; Northwestern University auditorium, the students feel the patriotic brutal destruction, the spirit of perseverance from Yan City after the indomitable spirit. Of course, for the local type of new undergraduate colleges, the school material landscape, although not the history of washing, but there have been no faction of the celebrities living here, but the campus material landscape to the school's original, traditional and unique school concept, school characteristics and campus spirit properly integrated into the campus architecture and landscape design, to extract the most able to express the spirit of the campus architectural art symbols to create a suitable for their school architectural style, in order to teachers and students recognition, heritage, only have lasting vitality.

Condense Characteristics of the Campus Culture and Highlight the School Spirit. Chinese colleges and universities have always attached great importance to the cultivation of school spirit, often with school motto, school song, school badge for the most distinctive embodiment of the spirit of the school, and colleges and universities to rigorous, profound connotation and concise text interpretation of its purpose, school motto and school rules. However, young students are not necessarily able to understand the connotation and expectations behind these words. College students are energetic and have a wide range of interests, like to explore and try new things. Therefore, combined with the psychological development characteristics of the students in this age, referring to the practice of American colleges and universities, in a relaxed way that students can easily accept, the purpose of integration into a specific school color, carefully designed to represent the school characteristics of the school mascot, and in the opening ceremony, graduation ceremony, sports or other important activities to promote and publicity. Huazhong Normal University in the two lively and lovely little squirrel cartoon image to become the century mascot of the school, respectively, on behalf of the school boys and girls. In addition, the "Bo Bo" "Ya Ya" as the image of derivatives such as plush toys, cultural shirt, cards and other popular in the campus, the school also created a school mascot background wall for students to take pictures [6]. This approach not only enriched the students' campus cultural life, creating a campus culture atmosphere, vivid and 
lively to reflect the spirit of campus culture, more deep students of the school pride, a sense of belonging. Local colleges and universities should combine the local culture, school characteristics, the advantages of professional to create a relaxed and lively school symbol of goods, the development of school-run industry, production, learning, research combined with the production of university symbolic life or learning items, both school to create economic profits, but also for students to provide a platform for practice to promote local economic development will also play an important role, fully embodies the university's social value.

Create Classroom Culture and Spread the School Spirit. Classroom as an important position of education is the most important place to convey and nurture school spirit, and teachers are the devisors of the tone of classroom culture. In the United States, students from the junior high school began to flow classes, teachers usually in a fixed classroom office and teaching, teachers according to their own characteristics of the design of their own classroom, fresh and vivid layout of the interpretation of a subject, a feeling in the university classroom, from the trash to the chalk box, everywhere school color, the author at the Michigan State University during the visit to see some male teachers in the name of green and white (green and white is the school color) the tie, with a distinctive logo with the school briefcase, and even some teachers on the cup there are school mascot pattern, the teacher's feelings of the school which is slightly different. Teachers are the spirit of the school readers, passers, is the leader of the value, when the students inside and outside the classroom feel the teacher's passion and love of the school, the classroom is not only the temple of knowledge, but also inherited the school culture and school spirit

Improve the School Rules and Regulations and Lead the School Spirit. The pursuit of the realization of the value of life, human freedom and equality is the soul and core of contemporary university, but also the embodiment of the humanistic spirit of the university, and the construction of humanistic spirit requires the top design, the need for school rules and regulations. As a university, we must first respect people, certainly people, pay attention to the development of human personality, all from the people, people as a destination. This dominant value is reflected in the spiritual level of the school, the school is like a warm, harmonious family, home and everything can flourish.

For the local type of new undergraduate institutions in terms of the following aspects: First, to enhance the quality of school leaders and administrative staff, they represent a certain level of the school, determines the school's development track. In the United States, the mission of university administrators is to create all the conditions for teachers and students to provide services to provide human care, to maximize the promotion of teachers and students. In our country, the administrative layer is often the management, the administration often symbolizes the right, but it is difficult to contact with the service. When the administrative staff to change their minds, is willing to promote the growth of teachers and students advice, the whole school up and down the minds of the school, the school can get more long-term development. Second, improve the school system construction, the school system is to cultivate the school spirit indispensable foundation and guarantee, establish a harmonious and unified, people-oriented system, to establish teachers and students in learning, work, life, sense of security, satisfaction, happiness, students are willing to enrich their alma mater, teachers are willing to strive for the school, the school can be a prosperous.

Plan School Cultural Activities and Carry the School Spirit. School cultural activities are an important carrier of the spirit of the school and the media [7]. For the new undergraduate colleges, combined with the school characteristics, professional characteristics carefully designed classic cultural activities, highlight the distinctive spirit of the school, creating a strong campus atmosphere, with various activities, so that teachers and students within the "campus spirit" School spirit to become the common pursuit of all teachers and students. In addition, the school activities into local characteristics, combined with local customs, add local cultural elements, so that the school culture to lead the local community culture, universities and communities to promote mutual win and improve the school in the public minds of recognition, influence.

In short, in the context of the country's strong advocacy of the transition of colleges and universities, local colleges and universities should be based on the spirit of the school, campus 
culture, professional characteristics as the basis, to build cultural school strategy, the school can be developed by leaps and bounds.

\section{References}

[1]http://blog.sina.com.cn/s/blog_5fe5ddf20100re3h.html

[2]http://www.zhihu.com/question/28027315

[3] Zhu Jing. On the image shaping of Chinese universities from the application of mascot in American colleges and universities[J]. Journal of Literature Education, 2015 (8): 123-123

[4] Chen Ruisheng, Chen Yukun. On the concise of school spirit - Comment on some cases of school [J]. Education Development Research, 2010, 12: 61

[5] Xie Bin, Luo Tingting. Let the "school spirit" take root and mentality - also talk about "school spirit" to explore and nurture [J]. New Curriculum Guide, 2014, 10: 9

[6]http://news.163.com/11/0616/03/76KVA0NI00014AED.html

[7] Fu Yunsong. University campus construction should be extended from the material culture to spiritual culture [J]. Shanxi Architecture, 2010,36 (1): 12-13 